\title{
Review
}

\section{A Review of Honeybee Venom Allergens and Allergenicity}

\author{
Marta Burzyńska and Dorota Piasecka-Kwiatkowska *(D) \\ Department of Food Biochemistry and Analysis, Poznan University of Life Sciences, Mazowiecka 48 str., \\ 60-623 Poznan, Poland; marta.burzynska@up.poznan.pl \\ * Correspondence: dorota.piasecka-kwiatkowska@up.poznan.pl; Tel.: +48-61-8-48-73-47
}

Citation: Burzyńska, M.;

Piasecka-Kwiatkowska, D. A Review of Honeybee Venom Allergens and Allergenicity. Int. J. Mol. Sci. 2021, 22, 8371. https://doi.org/10.3390/ ijms22168371

Academic Editor: Yuri N. Utkin

Received: 8 July 2021

Accepted: 31 July 2021

Published: 4 August 2021

Publisher's Note: MDPI stays neutral with regard to jurisdictional claims in published maps and institutional affiliations.

Copyright: (c) 2021 by the authors. Licensee MDPI, Basel, Switzerland. This article is an open access article distributed under the terms and conditions of the Creative Commons Attribution (CC BY) license (https:/ / creativecommons.org/licenses/by/ $4.0 /)$.

\begin{abstract}
Honeybee venom is a source of proteins with allergenic properties which can result in in various symptoms, ranging from local reactions through to systematic life-threatening anaphylaxis, or even death. According to the World Allergy Organization (WAO), honeybee venom allergy is one of the most common causes of anaphylaxis. Among the proteins present in honeybee venom, 12 protein fractions were registered by the World Health Organization's Allergen Nomenclature Sub-Committee (WHO/IUIS) as allergenic. Most of them are highly immunogenic glycoproteins that cross-react with IgE and, as a consequence, may give false positive results in allergy diagnosis. Allergenic fractions are different in terms of molecular weight and biological activity. Eight of these allergenic fractions have also been identified in honey. This explains frequent adverse reactions after consuming honey in people allergic to venom and sheds new light on the causes of allergic symptoms in some individuals after honey consumption. At the same time, it also indicates the possibility of using honey as a natural source of allergen in specific immunotherapy.
\end{abstract}

Keywords: honeybee venom allergens; Apis mellifera; venom immunotherapy

\section{Introduction}

Alongside drugs and food, insect venom is one of the most frequent elicitors of anaphylaxis. In the countries of Central Europe, there are two families of Hymenoptera which cause allergic reactions: Apidae-honeybees (Apis mellifera) and bumblebees (Bombus spp.); and Vespidae - the common wasp (Vespula vulgaris) and European hornet (Vespa crabro). The majority of cases of anaphylactic reaction occur after a sting by honeybee, due to the higher frequency of attacks. Honeybee venom (HBV) allergy is the second most common form of allergy to Hymenoptera venom, and is especially prevalent in children, beekeepers and their family members, and people who are more likely to be stung [1]. While IgE specific (sIgE) to Hymenoptera venom are found in around $20 \%$ of the general population, sIgE antibodies to bee venom are found in 30\% of honey-allergic patients [2]. Although the exact incidence of allergy to honey is unknown, it has been estimated to be less than $0.001 \%$ of the population [3]. Allergenic proteins were first identified in honey in the 1990s [4,5]. Recently, Erban et al. [6] confirmed the presence of Api m 10 (icarapine) and Api m 11b (MRJP9) in all tested honey samples $(n=13)$. Additionally, Api m 2 (hyaluronidase), Api m 7 (serine protease CUB) and Api $\mathrm{m} 3$ (acid phosphatase) analogues were detected in eight honey samples, whereas, Api $m 1$ (phospholipase A2), Api m 4 (melittin) and Api $\mathrm{m} 12$ (vitellogenin) were found in one sample. This information sheds new light on the causes of allergic symptoms after consumption of honey. Although pollen from nectar plants is the main protein component of honey [7], the allergenic properties of honey may also result from the presence of secretions from the salivary and hypopharyngeal glands of honeybees [8,9]. When considering the allergenic properties of honey, it should also be taken into account that honey contains pollen from wind-pollinated plants [10,11]. The average pollen content of these plants can be $6.5-7.4 \%$ [12]. To understand the causes of allergy to honey, detailed research is necessary in order to explain the mechanisms of the migration of potentially allergenic fractions into honey and the possible implications of this 
process. In the future, such research may not only enable the prevention of allergy to honey, but also allow for the use of honey as a new method of immunotherapy to Hymenoptera venom allergy (HVA) or allergies to inhaled antigens [6]. This review explores a large number of studies investigating individual allergenic molecules of the honeybee, with a focus on explaining the causes of allergenicity.

\section{Epidemiology of Honeybee Venom Allergy}

According to the World Allergy Organization (WAO), HVA is one of the most common causes of allergies in adults which can lead to anaphylaxis [13]. In Poland, the most common causes of anaphylaxis include Hymenoptera stings and bites (41.4\%), followed by food $(29.8 \%)$, and drugs and other medical products (17.4\%) [14]. Sensitivity to Hymenoptera venom occurs in $27-40 \%$ of the general adult population and in up to $50 \%$ of children $[2,15]$. The risk of a systemic reaction in patients with undiagnosed allergies to the venom of black-winged insects ranges from 3.3 to $5 \%$ [2]. Large local injection site reactions occur in up to $26 \%$ of the general population and are defined as swellings larger than $10 \mathrm{~cm}$ in diameter lasting $24-48 \mathrm{~h}[16,17]$. A total of $15-20 \%$ of general population tests positive for $\operatorname{IgE}(\mathrm{sIgE})$, but most people do not experience dangerous symptoms after a sting. Allergic reactions are more often observed in adults. Anaphylaxis occurs in 0.3 to $7.5 \%$ (or $0.85-5 \%$, according to other sources) of sting cases [18]. In beekeepers, the statistics are different. In this group, excessive local reactions occur in $38 \%$ of sting cases (11.8\% in Poland), and generalised ones in $14-43 \%$ cases $(8.9 \%$ in Poland) $[19,20]$. According to the available data, in Poland the number of people who die every year due to hypersensitisation caused by venom ranges from several to a dozen or so every year. Based on the data collected worldwide to date, the death rate related to stings is $0.09-0.13$ per million people/year [13].

\section{Mechanism of Hymenoptera Venom Allergy (HVA)}

Allergy is a hypersensitivity reaction of the immune system and, according Gel and Combs, classification can be categorised into four subtypes (Table 1) [21].

Table 1. Classical Gel Combs classification of hypersensitive reactions.

\begin{tabular}{ccc}
\hline $\begin{array}{c}\text { Type of } \\
\text { Hypersensitivity }\end{array}$ & Mediated by & Effector Mechanism \\
\hline I & IgE & $\begin{array}{c}\text { mast cells degranulation and release of histamine and } \\
\text { other inflammatory mediators-immediate reaction }\end{array}$ \\
\hline II & IgG, IgM & $\begin{array}{r}\text { leading to the complement system activation and cell } \\
\text { damage or lysis—cytotoxic reaction }\end{array}$ \\
III & IgG, IgM & $\begin{array}{c}\text { build-up immune complexes resulting in complement } \\
\text { system activation, which leads to polymorphonuclear } \\
\text { leukocytes (PMNs) chemotaxis and eventually causing } \\
\text { tissue damage-complex reactions }\end{array}$ \\
\hline IV & T-cells & $\begin{array}{l}\text { T-cells or macrophages are activated as result of cytokine } \\
\text { release leading to tissue damage-delayed-type reaction }\end{array}$ \\
\hline
\end{tabular}

While there are a variety of mechanisms of the Hymenoptera venom allergy (HVA), the most common mechanism is the type I hypersensitivity reaction mediated by a venom allergen-specific IgE bound to the high-affinity FCRI receptor on mast cells and basophils. On allergen cross-linking of these receptors, mediators (e.g., histamine) are released [22]. Symptoms following a honeybee sting usually appear within $30 \mathrm{~min}$ and are often accompanied by skin reactions, such as itching, redness, hives and angioedema, while systemic reactions, including anaphylaxis, are relatively rare in the general population [23]. However, some people with high concentrations of sIgE do not show clinical manifestations of allergy, and some patients with very low or even undetectable levels of sIgE may experience life-threatening systemic reactions. There is evidence that the complement system may play an important role in the manifestation of the clinical symptoms of allergy to bee 
venom [24]. There are also other possible mechanisms of allergy to Hymenoptera venom in the form of type III (immune complex reaction) and type IV (delayed-type reaction) hypersensitivity reactions [25]. A type III reaction can lead to various syndromes, depending on the antibodies produced. The production of IgG antibodies directed against venom antigens may result in a serum sickness-like syndrome and glomerulonephritis caused by the deposition of immune complexes containing IgG and venom antigens [20]. Even in $20 \%$ of people who are allergic, the hypersensitivity reaction may be biphasic, with the second phase developing 1-72 $\mathrm{h}$ after the sting [26]. Responses to stings can also take the form of nonimmune (i.e., toxic) reactions.

In addition, most allergens of Hymenoptera venom are glycoproteins, in which the carbohydrate residue, an alpha-1,3 fucose bond to the $\mathrm{N}$-glycan core (CCD—cross-reacting carbohydrate determinant), is highly immunogenic, cross-reacting with $\operatorname{IgE}$. This, as a consequence, may give false-positive results of allergy diagnosis [27-29]. This mechanism is primarily found in patients with double sensitisation to the venom of yellow jackets or honeybees [30,31] and/or with polysensitisation to pollen allergens [32]. Glycoproteins are very common in pollen, food and Hymenoptera venoms. Studies on the presence of anti-CCD IgE in the sera of allergy sufferers indicate that the presence of these antibodies does not cause visible clinical symptoms $[19,23,27,28]$. For example, patients allergic to grass pollen, whose serum IgE reacts with $\mathrm{Phl}$ p4, one of the allergens found in timothy grass (Phleum pratense), also reacted to Api $\mathrm{m} 1$, even though they were not sensitised to bee venom [33]. Glycosylated proteins with CCD have a high frequency of IgE reactivity but low allergenicity, which is why sensitised individuals develop $\operatorname{IgE}$ antibodies against the antigenic CCD. Therefore, the positive diagnosis in patients sensitive to Hymenoptera venom can be also due to the presence of CCD-sIgE in their serum [34].

\section{Symptoms of Bee Sting Allergy}

A normal local reaction (NR) is the most common symptom of a bee sting. It is characterized by the appearance of slight swelling, erythema and pain after the sting. The symptoms may last for any time from a few minutes up to several hours. The reaction may be more severe if the sting affects the mucosa (e.g., the mouth) or an area rich in loose connective tissue (e.g., the eyelids, fingertips or lips). In addition, there may be complications in the form of sting site infection, accompanied by a fever and enlargement of the surrounding lymph nodes. Some allergy sufferers may develop a large local reaction (LLR), which is caused by the late phase of the allergic reaction. This involves a swelling more than $10 \mathrm{~cm}$ in diameter and lasting more than $24 \mathrm{~h}$, which intensifies 6-12 $\mathrm{h}$ after the sting and reaches its largest size after 24-48 h. Swelling may be accompanied by malaise, chills, fever or headache, or an inflammatory reaction along the lymphatic vessels. The aforementioned changes resolve slowly and gradually over several days. Large local reactions may be life-threatening if the sting site is in the area of the upper respiratory tract, but the risk of a generalised reaction is not significantly increased in the case of subsequent stings [35]. Another classification of symptoms is the breakdown of a generalised allergic reaction according to the classical four-grade scale developed by Mueller [27] (Table 2).

Another type of symptoms is a generalised toxic (non-immune) reaction, which appears in patients who have been stung by many insects at the same time and is based on the description of their symptoms, including: rhabdomyolysis; damage to the heart muscle; liver or kidney dysfunction; haemolytic anaemia; haemorrhagic diathesis; and disseminated intravascular coagulation syndrome. The fifth classification of symptoms includes very rare, atypical reactions (e.g., serum sickness, vasculitis or Guillain-Barre syndrome). Cardiac arrhythmias and acute coronary syndrome may occur during anaphylaxis. There is also a specific form of anaphylaxis referred to as allergic myocardial infarction (Kounis syndrome), caused by the narrowing of coronary arteries under the influence of mediators released from mast cells in the vascular wall. The first symptoms of an anaphylactic reaction usually appear a few minutes after the sting and disappear completely within the following few hours [25]. 
Table 2. Severity degree of allergy to Hymenoptera venom according to Mueller scale [22].

\begin{tabular}{cl}
\hline Degree & \multicolumn{1}{c}{ Symptoms after a Sting } \\
\hline 0 & extensive local reaction (swelling $>10 \mathrm{~cm}$ lasting $>24 \mathrm{~h}$ ) \\
\hline I & hives, itching \\
\hline II & $\begin{array}{l}\text { any symptom listed above and at least two of the following: Quincke's oedema (as a } \\
\text { single symptom qualifies as degree II), chest tightness, nausea, vomiting, diarrhoea, } \\
\text { abdominal colic, dizziness }\end{array}$ \\
\hline III & $\begin{array}{l}\text { any of the abovementioned symptoms and at least two of the following: dyspnoea } \\
\text { (as a single symptom qualifies as degree III), wheezing (as a single symptom } \\
\text { qualifies as degree III), wheezing (as a single symptom it qualifies as degree III) and } \\
\text { dysphagia, weakness, a sense of being in a life-threatening situation, anxiety }\end{array}$ \\
\hline IV & $\begin{array}{l}\text { any symptoms listed above and at least two of the following: drop in blood pressure, } \\
\text { fainting, loss of consciousness, urinary and stool incontinence, cyanosis }\end{array}$ \\
\hline
\end{tabular}

In anaphylactic shock after the injection of the Hymenoptera venom, common gastric symptoms such as nausea and vomiting are observed, with tingling in the arms and legs and restlessness. Severe anaphylaxis affects the respiratory and cardiovascular systems. The characteristic symptoms are bronchospasm and shortness of breath, tachycardia, hypotension, sweating and loss of consciousness. Urinary and faecal incontinence occurs with severe circulatory dysregulation, and the most severe systemic reactions lead to cardiac and respiratory arrest. When cardiovascular or respiratory symptoms appear after initial skin manifestations such as urticaria, the clinical diagnosis of HVA is easier [23].

\section{Venom Immunotherapy}

Causal treatment in the form of allergen immunotherapy (AIT), called venom immunotherapy (VIT) in the case of the Hymenoptera venom, is an effective therapy for the allergic symptoms of stings in people allergic to a proven IgE-dependent mechanism of the reaction. Immunotherapy with the venom of wasps and bees (VIT) is the only method used to radically reduce the risk of a systemic reaction to the stings of these species of insects (Hymenoptera venom allergy systemic allergic reactions-HVA-SYS) [36].

Qualification for VIT is based on clinical criteria and diagnostic tests confirming the presence of sIgE against insect venoms. Systemic reaction is understood as a generalised IgE-dependent reaction of the body to an insect sting and is classified on a four-grade scale of reaction severity developed by Mueller (1966) [27] (Table 2). Insect venom allergen immunotherapy is recommended for patients with life-threatening HVA symptoms-HVASYS III-IV, for people with a high degree of exposure to stings (bee breeders) or people with comorbidities increasing the risk of a severe reaction $[29,33]$.

VIT involves the repeated administration of increasing doses of the allergen (aqueous solutions or extracts of venom adsorbed on aluminium hydroxide) in order to achieve tolerance to the allergen. For HVA, only injection immunotherapy is used. The initial phase of the treatment (VIT induction), usually starts with a dose of $1 \mu \mathrm{g}$ of venom. The dose of the allergen is then gradually increased in order to reach the standard value, (i.e., $100 \mu \mathrm{g}$ of venom). Upon reaching the maintenance dose, the patient demonstrates clinical tolerance (short-term efficacy). For long-term effectiveness, it is necessary to continue therapy for the next 3-5 years [31].

The objective of immunotherapy is to direct the immune response from humoral to cellular immunity. The intention of specific immunotherapy is to reduce the synthesis of IgE antibodies by B lymphocytes through to exposure to escalating doses of an allergen administered under the control of an allergist. During treatment, the concentration of the allergen is increasing. This increase encourages the production of IL-12 by Langerhans cells and macrophages. Following this, IL-12 inhibits the production of Th2-type cytokines (IL-4, IL-5, and IL-13) and stimulates the synthesis of Th1-type cytokines (including IFN- $\gamma$ ). As a result of these processes, the production of IgE is inhibited. The presence of IL-10, 
which strongly inhibits the production of specific IgE and increases the level of specific IgG4, also plays an important role in the mechanism of immunotherapy. This occurs because IL-10 inhibits the excitation of mast cells and eosinophils and is responsible for the induction of T-cell anergy [37-39]. Specific immunotherapy involves the risk of several side effects, both local and systemic in nature. Systemic complications are found in $8-20 \%$ of patients undergoing therapy. They appear 3-6 times more often during immunotherapy with bee venom than with wasp venom, and more often during the initial phase than during the maintenance phase [35,39]. In a study by Kolaczek et al. [33], the side effects of immunotherapy occurred in 64 out of 180 study participants (43.8\%). Early and late side effects of VIT were more common in the maintenance phase than in the induction phase $(26.7 \% / 17.8 \%)$, while systemic adverse reactions were more common in the induction phase of immunotherapy. Most of these adverse reactions were early reactions (up to $30 \mathrm{~min}$ after the administration of a dose of immunotherapy) and they were observed in 4 patients who had been desensitised with wasp venom $(2.7 \%)$ and in 6 patients who had been desensitised with bee venom (17.6\%). In only one case was the administration of adrenaline required. Early and late side effects in both the induction phase and the maintenance phase were more common in patients who were allergic to bee venom [34]. Antigen-specific immunotherapy is currently the only causal treatment of allergic diseases in bee venom allergy [40]. The applied treatment reduces the allergen sensitivity in an allergic person, resulting in the elimination or reduction of the severity of disease symptoms. The beneficial effect of the treatment is maintained for many years after it is completed [35]. Boyle et al. [41] argue that insect venom immunotherapy is an effective method of preventing further allergic reactions to insect stings, which may improve the quality of life for people suffering from bee venom allergies. However it is important to note that treatment with bee venom extract carries a low but nonetheless significant risk of systemic side effects which may affect up to $40 \%$ of patients [42]. In this context, the economic analysis showed that VIT is cost-effective only in individuals who are stung frequently (e.g., beekeepers) or in cases where an improvement in the quality of life for the patient is considered [43]. This prompts a search for new immunotherapeutic strategies that will be safer, more convenient, widely available, free from side effects and will provide high treatment effectiveness.

\section{The Major Honeybee Allergens}

The World Health Organization's Allergen Nomenclature Sub-Committee (WHO/IUIS) has established a method to classify known allergens. This system is based on the name of the genus, the species from which a given allergen has been isolated and the number used to mark the sequentially reported allergens [44]. A total of 12 allergenic fractions from the honeybee (Apis mellifera) are known and registered, and they can be found in the official database of allergens of the WHO/IUIS Allergen Nomenclature Sub-Committee [45]. As many as 11 of these allergens come from bee venom (Api m 1-10, Api m 12), while two allergenic isoforms are derived from bee secretions from the royal jelly-producing glands (Api m 11a (0101) and Api m 11b (0201)).

Bee venom glands produce venom, which is a complex mixture of compounds that includes proteins, peptides, amino acids, phospholipids, sugars, biogenic amines, volatile compounds, pheromones, and a water content close to $80 \%$ [46-48]. The composition of HBV proteins is highly complex, including at least 113 identified proteins and peptides [49]. The complexity is increased further by N-glycosylation sites and the heterogeneity of proteins (e.g., Api $\mathrm{m} 1[50,51]$ or Api $\mathrm{m} 6[52,53])$. The allergenic components of bee venom are enzymes and glycoproteins with a molecular weight ranging from 3 to $200 \mathrm{kDa}$. Honeybee venom also contains numerous small-molecule substances, including pheromones and peptides showing a local toxicity. In terms of their biological role, allergens identified in the venom are divided into major and weaker allergens, assuming that a percentage of over $50 \%$ of allergic persons will have positive specific IgE antibodies for a particular component of the venom as a criterion for distinguishing between them [54]. Pheromones are compounds used for communication (e.g., they convey to other bees information 
about imminent danger and the need to defend themselves). On the other hand, the main constituent of honeybee venom consists of enzymatic proteins, such as hyaluronidase, acid phosphatase and phospholipase $\mathrm{A} 2$, as well as peptides and non-enzymatic proteins including melittin, secapin, MCD-peptide, apamine (which is a neurotoxin), procamine and minimin. From the point of view of allergic reactions, the following are distinguished: phospholipase A2 (Api m 1) - an enzyme with a cytotoxic effect; hyaluronidase (Api m 2); acid phosphatase (Api m 3); and melittin (Api m 4) with haemolytic properties that can stimulate and adversely affect heart rate. Other components of honeybee venom include vasoactive amines: histamine, which causes pain and lowers blood pressure; dopamine and catecholamines with locally high cytotoxic potential, whose extent may increase in the case of multiple stings [55-59]. The overview of honeybee (Apis Meliffera) venom allergens, including the number of potential glycosylation sites, are summarised in Table 3 whereas Table 4 presents the rates of sensitisation to recombinant HVA in HBV patients.

Figure 1 presents structures generated on PHYRE2 server 3D structures models of HBV allergens $[60,61]$. All models were prepared with a high confidence value $(>90 \%)$, making the models confident. The percentage of residues modelled is informative regarding the equivalence to identical template residues in the generated alignment. For extremally high accuracy models, the percentage should be above $30-40 \%$, but even at very low percentage $(<15 \%)$ they can be very useful as long the confidence is high [62]. The amino acid sequences of allergens were loaded from the UniProt/Swiss-Prot protein knowledgebase [63] and intensive mode was chosen for modelling.

Table 3. Characteristics of allergenic fractions of honeybee (Apis Mellifera) according to WHO/IUIS Allergen Nomenclature Sub-Committee [45], characterisation and position of N-glycosylation according to the UniProt/Swiss-Prot protein knowledgebase [63].

\begin{tabular}{|c|c|c|c|c|c|c|c|}
\hline Allergen & Tissues & Biochemical Name & $\begin{array}{c}\text { MW } \\
{[\mathrm{kDa}]}\end{array}$ & Chain & $\begin{array}{c}\text { Route of Allergen } \\
\text { Exposure }\end{array}$ & $\begin{array}{c}\text { Dry Weight } \\
{[\%]}\end{array}$ & $\begin{array}{c}\text { Position of } \\
\text { N-glycosylation }\end{array}$ \\
\hline Api m 1 & Venom gland & Phospholipase A2 & 16 & 167 & Injection & $10-12$ & 46 \\
\hline Api m 2 & Venom gland & Hyaluronidase & 44 & 382 & Injection & $1-3$ & $115 ; 263$ \\
\hline Api m 3 & Venom gland & $\begin{array}{c}\text { Venom acid } \\
\text { phosphatase Acph-1 }\end{array}$ & 43 & 388 & Injection & $1-2$ & $182 ; 228 ; 366$ \\
\hline Api m 4 & Venom gland & Melittin & 3 & 70 & Injection & $\sim 50$ & - \\
\hline Api m 5 & Venom duct & Dipeptidylpeptidase IV & 100 & 775 & Injection & $>1$ & $\begin{array}{r}68 ; 239 ; 473 ; 505 ; \\
578 ; 631 ; 689 ; 694\end{array}$ \\
\hline Api m 6 & Venom gland & $\begin{array}{l}\text { Api m 6.03/ } \\
\text { Api m } 6.04\end{array}$ & 8 & 92 & Injection & $1-2$ & - \\
\hline Api m 7 & Venom duct & CUB serine protease & 39 & 405 & Injection & $>1$ & $113 ; 209 ; 229$ \\
\hline Api m 8 & Venom duct & Carboxylesterase & 70 & 557 & Injection & $>1$ & $\begin{array}{c}145 ; 374 ; 478 ; 528 ; \\
542\end{array}$ \\
\hline Api m 9 & Venom duct & $\begin{array}{c}\text { Serine } \\
\text { carboxypeptidase }\end{array}$ & 60 & 467 & Injection & $>1$ & $\begin{array}{c}\text { 130; } 169 ; 304 ; 322 \\
344\end{array}$ \\
\hline Api m 10 & Venom duct & $\begin{array}{l}\text { Icarapin variant 2, } \\
\text { carbohydrate-rich } \\
\text { protein }\end{array}$ & $50-55$ & 223 & Injection & $>1$ & $126 ; 142 ; 168 ; 193$ \\
\hline $\begin{array}{l}\text { Api m 11 } \\
\text { Api m 11a } \\
\text { (0101) }\end{array}$ & $\begin{array}{l}\text { Hypopharyngeal } \\
\text { glands }\end{array}$ & $\begin{array}{l}\text { Major royal jelly } \\
\text { protein (MRJP)- } \\
\text { deglycosylated forms } \\
\text { MRJP } 8\end{array}$ & 60 & 415 & $\begin{array}{l}\text { Injection/ } \\
\text { food }\end{array}$ & - & \\
\hline $\begin{array}{l}\text { Api m 11b } \\
\text { (0201) }\end{array}$ & & MRJP 9 & 65 & 423 & & & \\
\hline Api m 12 & Venom gland & Vitellogenin & 200 & & Injection & - & $296 ; 1067$ \\
\hline
\end{tabular}




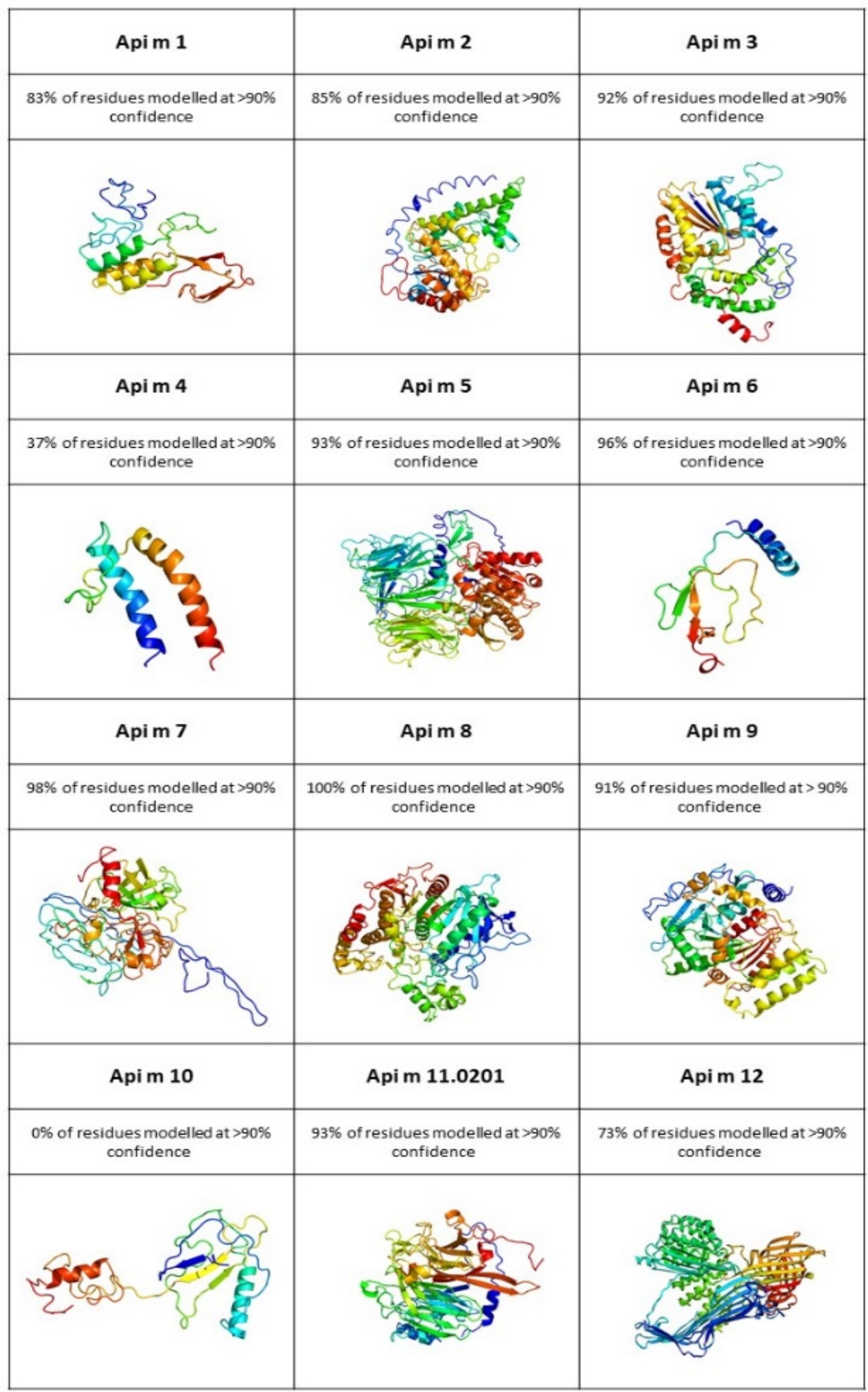

Figure 1. Structural features of selected Hymenoptera venom allergens. Three-dimensional structures of all HBV, $100.0 \%-90.0 \%$ confidence by the single highest scoring template, Image rainbow-colouring from $\mathrm{N}$ to (C-terminus). The structures were generated by structural modelling (PHYRE2 server [60,61]). 
Table 4. Rates of sensitisation to honeybee venom recombinant allergens in Hymenoptera venom allergic patients.

\begin{tabular}{|c|c|c|c|}
\hline Allergen & $\begin{array}{l}\text { Sensitisation } \\
\text { Frequency (\%) }\end{array}$ & No. of Patients & References \\
\hline \multirow{7}{*}{ Api m 1} & 79 & 34 & [64] \\
\hline & 57 & 175 & [65] \\
\hline & 78 & 100 & [66] \\
\hline & 72 & 144 & [67] \\
\hline & 97 & 100 & [68] \\
\hline & 68 & 16 & [69] \\
\hline & $126 / 83$ & $54 / 66$ & [70] \\
\hline Api m 2 & 48 & 144 & [67] \\
\hline \multirow{2}{*}{ Api m 3} & 50 & 144 & [67] \\
\hline & 38 & 40 & [71] \\
\hline \multirow{3}{*}{ Api m 4} & 27 & 82 & [64] \\
\hline & 42 & 40 & [66] \\
\hline & 23 & 144 & [67] \\
\hline \multirow{2}{*}{ Api m 5} & 60 & 35 & [72] \\
\hline & 58 & 144 & [67] \\
\hline Api m 6 & 26 & 31 & {$[73]$} \\
\hline Api m 8 & 28 & 46 & [74] \\
\hline \multirow{2}{*}{ Api m 10} & 49 & 68 & [75] \\
\hline & 62 & 144 & [67] \\
\hline $\begin{array}{l}\text { Api m 11a (0101) } \\
\text { Api m 11b (0201) }\end{array}$ & $15 / 34$ & 47 & [76] \\
\hline Api m 12 & 44 & 45 & [77] \\
\hline
\end{tabular}

Api $m 1$ is a phospholipase A2 (EC: 3.1.1.4) (short name: bvPLA2), which is an enzyme protein with a molecular weight of about $16 \mathrm{kDa}$, which is one of the main allergens of bee venom. It accounts for 10-12\% of the dry weight of bee venom and is the most active known phospholipase [78]. Phospholipase A2 consists of a single chain of 128 amino acid residues and contains attached carbohydrate residues. The secretion of this protein into the venom follows a seasonal pattern. This variation is synchronised with the melittin variation (i.e., their production increases at the same pace) [79]. The allergenic effect of Api $\mathrm{m} 1$ is related to the activity of an enzyme that is involved in the degradation of cell membrane lipids. The secreted phospholipases A2 are enzyme proteins with a molecular weight of 14 to $18 \mathrm{kDa}$, which contain about 6-8 disulphide bridges that stabilise the proper tertiary structure of the enzyme [80]. Phospholipase A2 belongs to the acyl hydrolases, catalysing the calcium-dependent hydrolysis of the 2-acyl groups in 3-sn-phosphoglycerides [81]. During this reaction, fatty acids (e.g., arachidonic acid) and lysophospholipid are formed, causing degradation of the structure of cell membranes. These enzymes are responsible for the formation of intracellular eicosanoid signalling molecules, such as arachidonic acid metabolites, which can act as secondary messengers in the central nervous system. Secreted phospholipases are also involved in the process of endo- and exocytosis and reorganisation of the cytoskeleton. Under the influence of the enzymatic activity of phospholipases, hydrolysis of membrane phospholipids occurs and the membrane loses its potential and becomes permeable to $\mathrm{Ca}^{2+}$ ions. This increase in the concentration of $\mathrm{Ca}^{2+}$ ions in the cytoplasm causes disturbances in mitochondrial function. 
In addition, cytoskeleton-degrading calcium-dependent proteases are activated. It also results in the activation of calcium-dependent cytosolic phospholipases hydrolising intracellular membranes and, consequently, disintegrating the nerve cell [82]. IgE antibodies specific to Api $\mathrm{m} 1$ are present in the sera of $97 \%$ of individuals allergic to bee venom [68]. The presence of IgE reactivity to commercially available rApi $\mathrm{m} 1$ was detected in $72.2 \%$ of patients with HBV allergy $(n=144)$ with the use of ImmunoCap [67]. Table 3 presents the rates of sensitisation to recombinant Api $\mathrm{m} 1$ in HBV patients noted by different authors. Api $\mathrm{m} 1$ is the first allergenic fraction that was identified in the tested honey samples [6].

Api $\mathrm{m} 2$ is hyaluronidase (EC: 3.2.1.35) (short name: Hya), which is, according to the WHO/IUIS classification, a protein with a molecular weight of $44 \mathrm{kDa}$, showing hyaluronidase activity and containing 382 amino acids. Although Api m 2 only accounts for $1-2 \%$ of the dry weight of honeybee venom, it is considered to be its second major allergen. Hyaluronidases are the enzymes which are responsible for the degradation of hyaluronic acid, thus increasing the permeability of connective tissue and reducing the viscosity of body fluids, which facilitates the spread of toxins and injected fluids. One of the three groups of hyaluronidases are endo $\beta-\mathrm{N}$-acetylhexosaminidases (EC: 3.2.1.35). These are the enzymes found in mammals, as well as in the venoms of snakes and Hymenoptera species [83]. They hydrolyse $\beta-1,4-$ glycosidic bonds in hyaluronic acid, yielding the main decomposition products of hyaluronic acid: tetra and hexasaccharides [84]. Aside from their hydrolytic activity, the enzymes of this group can also transglycosylate, which results in the formation of di-, tri-, -octa- and nonasaccharide units during the degradation of hyaluronic acid [85]. Hyaluronidase found in the venom of Hymenoptera (bees, wasps, hornets) may cause allergic reactions, including anaphylactic shock. About half of the population allergic to bee venom have hyaluronidase-specific IgE antibodies [78]. Due to the similarity of the structures of bee and wasp hyaluronidase, this allergen is the main cause of cross-reactions with specific IgE antibodies directed against the venom of both insects [86]. However, in the opinion of some authors, the cross-reactivity of $\operatorname{IgE}$ antibodies between bee and wasp venoms is not due to the similar structure of their hyaluronidases but instead due to the reactions with cross-reacting carbohydrate determinants (CCDs) which are secreted by these insects. This thesis calls into doubt the role of hyaluronidase as the second most allergy-provoking component of bee venom after phospholipase A2 [87]. In people allergic to Hymenoptera venom, the incidence of anti-CCD IgE is generally more than $20 \%$ [88]. IgE reactivity to commercially available recombinant Api $\mathrm{m} 2$ was demonstrated in $50.0 \%$ of patients with a HBV allergy (Table 3). Moreover, Erban et al. [6] detected the Api $\mathrm{m} 2$ allergen in eight of the analysed types of honey.

Api $\mathrm{m} 3$ is a venom acid phosphatase Acph-1, which is a protein with a weight of $43 \mathrm{kDa}$ belonging to the histidine acid phosphatase family (EC: 3.1.3.2), also known as phosphomonoesterase, which exhibits optimum activity in an acidic environment ( $\mathrm{pH}$ 4.4-4.8). It was first identified in the venom of the honeybee in the 1960s by Benton [89]. The allergen comprises 373 amino acids and contains 3 potential N-glycosylation sites and 2 disulphide bonds [71]. The isoelectric point of the protein is 5.64. Acid phosphatase detected in honeybee venom is an acidic protein resistant to higher temperatures [57]. Similarly to hyaluronidase (Api $\mathrm{m}$ 2), it is present in bee venom in a small amount, constituting only $1-2 \%$ of the venom [78]. Antibodies to acid phosphatase are detected in $60 \%$ of allergy sufferers (Table 3). Acid phosphatase can stimulate sensitised basophils to release histamine, but the mechanism of its action is not fully explained [90]. As such, an analysis were carried out that revealed the presence of analogues to Api $m 3$ (acid phosphatase) across all tested types of honey $(n=13)$ [6].

Api $\mathrm{m} 4$ is a melittin (short name: MEL/MLT) [1.C.18.1.1] which is a cytotoxic 26 amino acid peptide with a low molecular weight of $3 \mathrm{kDa}$ of a hydrophobic nature (except for the hydrophilic C-terminus). It is found in two forms, due to cis-trans isomerisation at 56-Leu-Pro-57, in which the trans conformation is the major form [91]. Melittin is the main toxin found in bee venom with strong haemolytic and antimicrobial activities [92]. It is the main component of the weight of bee venom, accounting for about half of its dry weight 
(40-60\%) [93]. Api m 4 has allergenic properties much lower than those of phospholipase A2 or hyaluronidase. Melittin acts on the lipid layer of cell membranes and has strong lytic properties. This peptide acts synergistically with phospholipase A2. Melittin attaches to the lipid bilayer and disrupts its structure, resulting in the susceptibility of membrane phospholipids to the enzymatic action of phospholipase A2. As a consequence, these phospholipids cause cell lysis (they are responsible for erythrocyte haemolysis). Api $\mathrm{m} 4$ is also the main pain-inducing compound. It causes pain by activating primary nociceptor cells directly and indirectly, due to its ability to activate plasma membrane phospholipase A2 and its pore-forming activity [94]. Bee venom is characterised by bacteriostatic and bactericidal properties, precisely due to the presence of melittin. Api $\mathrm{m} 4$ shows strong cytotoxic and antiviral properties, as demonstrated in vitro studies on HIV-1. This peptide was found to directly inhibit the activity of the main structural genes of this retrovirus: gag and po [95]. Melittin is responsible for the cardiotoxicity of bee venom, causing both dysfunctions of heart contractions and morphological changes (e.g., balloon degeneration) [96]. This peptide can cause bradycardia, arrhythmias, and atrioventricular blocks [97]. Melittin also interferes with the transport of certain substances through the membranes of renal tubular cells [98]. It is also responsible for the local inflammation and pain sensations around the site of a bee sting [99]. The secretion of this protein into the venom follows a seasonal pattern. This variation is synchronised with the phospholipase A2 variation (i.e., their production increases at the same rate) [79]. The sera of $25-50 \%$ of patients allergic to bee venom contain the antibodies against Api m 4 [90]. Api m 4 was detected in only one of the analysed types of honey [6].

Api $\mathrm{m} 5$ is a protein with a molecular weight of $100 \mathrm{kDa}$ with dipeptidyl peptidase IV activity. Due to the structural similarity of this enzyme to the enzyme found in wasp venom (V. vulgaris)-Ves $\mathrm{v} 3$ is the second most common cause (after hyaluronidase) of allergenic cross-reactions between these insects [90]. Dipeptidyl peptidase IV is responsible for converting promelittin to melittin in the bee's venous tract and modulating the chemotactic activity of immune cells following insect stings [77,95]. Api m 5, also known as allergen $C$, is likely to be another major allergen recognised by sIgE in most HBV allergic patients [72]. However, it does not cross-react with other major bee venom allergens, including Api $\mathrm{m} 1$, Api $\mathrm{m}$ 2, Api $\mathrm{m} 3$, and Api $\mathrm{m} 4$ [100].

Api $\mathrm{m} 6$ constitutes only $1-2 \%$ of the dry weight of venom and is considered to be one of the weakest allergens of bee venom because the presence of specific IgE antibodies against this allergen was found in the blood serum in less than $40 \%$ of people allergic to venom $[54,74,91]$. It is a basic protein with a mass of $8 \mathrm{kDa}$, a low molecular weight, and an isoelectric point of 9.7 occurring in 4 isoforms (Api $m 6.01$ to 6.04) with the activity of a serine protease inhibitor [53,73]. Individual isoforms of this allergen have similar molecular weights and primary structures, with a characteristic central sequence consisting of 67 amino acids. They differ in up to 6 amino acids found at their amino and carboxyl terminals. There are 10 cysteine residues in the polypeptide chain, forming 5 disulphide bonds and stabilising the loop characteristic of canonical inhibitors, which is an epitope recognised by sIgE. In bee venom, all Api $\mathrm{m} 6$ isoforms occur in equimolar amounts and play a similar role in allergic reactions [53,73].

Api $\mathrm{m} 7$ is a $39 \mathrm{kDa}$ molecular weight protein with protease activity. The chain consists of 245 amino acids forming two domains, serine protease like (SPL) and CUB domain (CUB-protease) [101]. The structure of Api $\mathrm{m} 7$ suggests that the CUB domain is involved in interactions with natural substrates, while the SPL domain is likely to activate zymogens [102]. Api $\mathrm{m} 7$ shows high IgE binding activity. As many as $80 \%$ of sera of people allergic to bee venom confirmed immunoreactivity with the $39 \mathrm{kDa}$ fraction [101]. Additionally, an analysis was conducted that showed the presence of analogues to Api $\mathrm{m} 7$ (CUB serine protease) across all tested kinds of honey [6].

Api $\mathrm{m} 8$ is a carboxylesterase-6 (EC: 3.1.1.1) that belongs to the type-B carboxylesterase/ lipase family with a molecular weight of $70 \mathrm{kDa}$. The protein consists of 536 amino acids, is glycosylated in 4 positions, and also has two disulphide bridges. Api $\mathrm{m} 8$ is a negligible part 
of bee venom, constituting less than $1 \%$ of it, and its function is not yet fully explained [90]. On the other hand, $46 \%$ of serum samples from 28 individuals allergic to bee venom contained IgE, which reacted with rApi m 8.0101 [74].

Api $m 9$ is a venom serine carboxypeptidase (EC: 3.4.16.5), belonging to the peptidase S10 family. The protein consists of 449 amino acids and has $5 \mathrm{~N}$-glycosylation sites [103]. There is no information regarding immunogenic properties of Api $\mathrm{m} 9$.

Api $\mathrm{m} 10$ is the glycoprotein with a molecular weight of 50-55 kDa composed of 223 amino acids that was first identified by Peiren et al. [50]. The name proposed for Api $\mathrm{m} 10$ is icarapine, an artificial term linking "Icarus" from Greek mythology and the genus name "Apis" and indicating its unstable nature and rapid degradation [104].

About four out of five patients diagnosed with bee venom allergy show a specific IgE binding reaction to icarapine. Therefore, it is considered to be the major bee venom allergen, although its content in venom is marginal (less than 1\% DM). In addition, it is an allergen with activity independent of the cross-reacting CCD bicarbonate residues, which makes it a potentially crucial element to be used in the diagnosis of bee venom allergy [104]. Two best-known isoforms of Api $\mathrm{m} 10$ are variant 1 and 2 [52], both of which show independent IgE reactivity of cross-reactive carbohydrates (CCDs) [52,75]. A further seven additional Api m10 allergen isoforms present in the venom gland have recently been identified [105]. The immunoreactive properties of Api m 10 were first assessed on a larger scale in 2011 by Blank et al. [75]. They used a recombinant allergen devoid of cross-reactive carbohydrate determinants (CCD) in the ELISA test, and the results showed that $53 \%(27 / 51)$ of patients allergic to HBV and YJV and 47\% (8/17) of patients with HBV showed sIgE up to Api $m$ 10. Studies published by Köhler et al. [67] showed allergy to Api $\mathrm{m} 10$ ( $\geq 0.35 \mathrm{kUA} / \mathrm{l})$ in $62 \%(89 / 144)$ of patients allergic to HBV. In 2015, Api m 10 became commercially available (ImmunoCAP TM) for routine diagnosis. Shortly thereafter, Frick et al. [106] retrospectively analysed Api $\mathrm{m} 10$ sensitisation in a cohort of patients prior to HBV VIT and found Api $\mathrm{m}$ $10 \operatorname{sIgE}(\geq 0.35 \mathrm{kUA} / \mathrm{l})$ in $72 \%(83 / 115)$ of patients. Erban et al. [6], in turn, have confirmed the presence of Api $\mathrm{m} 10$ in all tested honey samples.

Api $\mathrm{m} 11$ occurs in two isoforms: major royal jelly protein (MRJP) 8 (Api m 11.0101a), with a molecular weight of $65 \mathrm{kDa}$, and MRJP9 (Api m 11.0201a), with a molecular mass of $60 \mathrm{kDa}$. Royal jelly proteins (MRJP) are a family of highly homologous proteins, so far identified only in the genus Apis, which constitutes $\sim 90 \%$ of all royal jelly (RJ) proteins [107]. Royal jelly is a substance produced by the secretory glands of worker bees and used to feed the larvae, which consists of 400 amino acids and contains six N-glycosylation sites. MRJP9 consists of 403 amino acids with three N-linked glycosylation sites [107]. MRJP9 has been identified independently in three different organs of the honeybee: antennae, in the mandibular glands [108], and the venom sac [50]. Human IgE antibodies recognizing MRJP1 are present in the sera of patients allergic to RJ, but also in the sera of people allergic to bee venom ( $38 \%$ of respondents) and in $52 \%$ of patients with respiratory and/or digestive allergies [109]. The authors concluded that IgE antibodies may arise in response to commonly inhaled allergens that cross-react with RJ proteins. The unequivocal identification of MRJP9 in bee venom by Peiren et al. [50] led to the hypothesis that the presence of this protein in bee venom may be one of the possible factors responsible for the development of allergies to RJ, at least in some sIgE patients. Consequently, some individuals allergic to RJ (without prior contact with RJ) may have developed an allergy through contact with the MRJP9 that is present in bee venom. The sequence similarity between MRJP1 and MRJP9 (and other royal jelly proteins) is high (74\%), so some immunological epitopes are likely common to the MRJP family of proteins. Antibodies against one MRJP have been reported to cross-react with the remaining RJ proteins [110]. According to Albert and Klaudiny [111], it is necessary to test the significance of the presented immunological and allergic effects. Nevertheless, for a full clarification of this issue, it is recommended that patients who are overreactive to bee stings monitor their symptoms carefully after consuming products containing RJ (e.g., honey). Prophylactic testing for MRJP-responsive antibodies in these patients can be effective in preventing life-threatening allergic reactions [112]. In a study by 
Erban et al., all of the honey samples which were tasted contained Api $\mathrm{m} 11$ both isoforms MRJPs, 8 and 9 [6].

Api $\mathrm{m} 12$ is a vitellogenin, with a molecular weight of $200 \mathrm{kDa}$. In most animals, both invertebrates (including honeybees) and vertebrates, vitellogenin is involved in the formation of the yolk during oogenesis [113]. Blank et al. [77] identified two vitellogenins in the venom of honeybees (Api m 12) and Vespula vulgaris (Ves v 6) using protein sequencing based on tandem mass spectrometry. The recombinant proteins of both allergens are glycosylated but CCD-free, since no reaction with rabbit anti-HRP (horseradish peroxidase) serum specific for $\alpha-1,3$ core $\mathrm{N}$-glycan fucosylation was detected. This feature excludes the occurrence of cross-reactivity, pointing to Api $\mathrm{m} 12$ and Ves $\mathrm{v} 6$ as interesting alternatives for improving the diagnosis of HBV and YJV allergies. In honey, Api $\mathrm{m} 12$ is present very rarely, and was detected in only one of thirteen analysed samples [6].

\section{Conclusions}

Due to the complexity of the composition of bee venom and the mechanisms of its distribution, the venom released by the bee may be one of many combinations that differ slightly in their content. This fact complicates the diagnosis of bee venom allergy, which is based on still-imperfect skin and serological tests. Additionally, eight venom allergens can also be found in honey. This creates the connection between honey and honeybee venom allergy and can explain their coexistence.

Honey allergy symptoms leading to anaphylaxis are relatively rare, but an increasing trend in the consumption of natural and unprocessed foods may increase the incidence of honey allergy. From this point of view, honey ought to be considered as the source of dangerous HVA. However, in honey, the amount of honeybee venom allergenic fractions is rather low, and honey can thus potentially be helpful in venom immunotherapy as the natural source of allergenic fractions. Furthermore, honey is also the source of biologically active plant pollen, of which some can also be allergenic which may limit such an application. Despite the multitude of studies on the allergenicity of bee venom and honey, there are still many issues that need to be clarified. Certainly, detailed studies explaining the reasons for the presence or absence of individual allergenic fractions of bee venom in honey are necessary. In the future, this would make it possible to develop more effective immunotherapies based on honey for people who are allergic to bee venom, without side effects.

Author Contributions: Conceptualization, M.B. and D.P.-K.; software, M.B.; validation, D.P.-K.; formal analysis, M.B.; investigation, M.B.; resources, M.B., D.P.-K.; data curation, M.B., D.P.-K.; writing-original draft preparation, M.B., D.P.-K.; writing-review and editing M.B., D.P.-K.; visualization, M.B.; supervision, D.P.-K.; project administration, M.B.; funding acquisition, M.B. All authors have read and agreed to the published version of the manuscript.

Funding: The APC was co-financed within the framework of the Polish Ministry of Science and Higher Education's program: "Regional Initiative Excellence" in the years 2019-2022 (No. 005/RID/ 2018/19)", financing amount 12000000 PLN.

Institutional Review Board Statement: Not applicable.

Informed Consent Statement: Not applicable.

Data Availability Statement: Not applicable.

Conflicts of Interest: The authors declare no conflict of interest. 


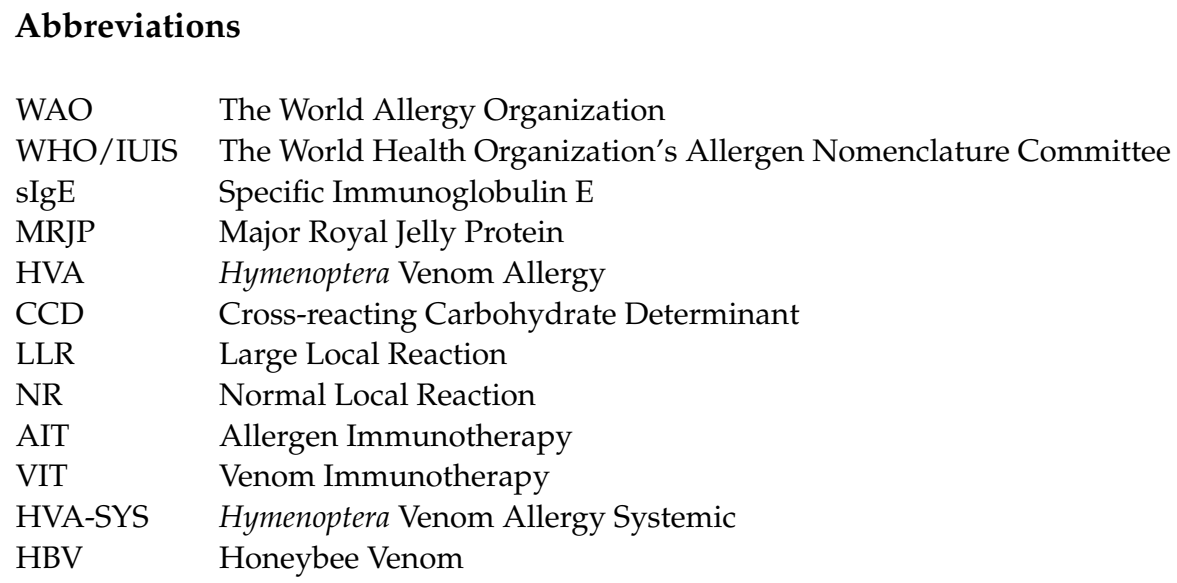

\section{References}

1. Muller, U.R. Bee Venom Allergy in Beekeepers and Their Family Members. Curr. Opin. Allergy Clin. Immunol. 2005, 5, 343-347. [CrossRef]

2. Sturm, G.J.; Kranzelbinder, B.; Schuster, C.; Sturm, E.M.; Bokanovic, D.; Vollmann, J.; Crailsheim, K.; Hemmer, W.; Aberer, W. Sensitization to Hymenoptera Venoms Is Common, but Systemic Sting Reactions Are Rare. J. Allergy Clin. Immunol. 2014, 133, 1635-1643. [CrossRef]

3. Hofer, T.; Wüthrich, B. Food Allergy. II. Prevalence of Organ Manifestations of Allergy-Inducing Food. A Study on the Basis of 173 Cases, 1978-1982. Schweiz. Med. Wochenschr. 1985, 115, 1437-1442.

4. Helbling, A.; Peter, C.; Berchtold, E.; Bogdanov, S.; Müller, U. Allergy to Honey: Relation to Pollen and Honey Bee Allergy. Allergy 1992, 47, 41-49. [CrossRef] [PubMed]

5. Bauer, L.; Kohlich, A.; Hirschwehr, R.; Siemann, U.; Ebner, H.; Scheiner, O.; Kraft, D.; Ebner, C. Food Allergy to Honey: Pollen or Bee Products? J. Allergy Clin. Immunol. 1996, 97, 65-73. [CrossRef]

6. Erban, T.; Shcherbachenko, E.; Talacko, P.; Harant, K. The Unique Protein Composition of Honey Revealed by Comprehensive Proteomic Analysis: Allergens, Venom-like Proteins, Antibacterial Properties, Royal Jelly Proteins, Serine Proteases, and Their Inhibitors. J. Nat. Prod. 2019, 82, 1217-1226. [CrossRef]

7. Da Silva, P.M.; Gauche, C.; Gonzaga, L.V.; Costa, A.C.O.; Fett, R. Honey: Chemical Composition, Stability and Authenticity. Food Chem. 2016, 196, 309-323. [CrossRef] [PubMed]

8. Escuredo, O.; Dobre, I.; Fernández-González, M.; Seijo, M.C. Contribution of Botanical Origin and Sugar Composition of Honeys on the Crystallization Phenomenon. Food Chem. 2014, 149, 84-90. [CrossRef] [PubMed]

9. Sak-Bosnar, M.; Sakač, N. Direct Potentiometric Determination of Diastase Activity in Honey. Food Chem. 2012, 135, 827-831. [CrossRef]

10. Ceglińska, K. Anemophilous Plant Pollen in Spring Specific Honeys from the Rzeszów Area. Acta Agrobot. 2008, 61, 59-64. [CrossRef]

11. Stawiarz, E. Pollen of Non-Nectariferous Plants in the Microscopic Image of Honyes of Some Communes of the Świętokrzyskie Voivodeship. Acta Agrobot. 2009, 62, 53-58. [CrossRef]

12. Burzyńska, M.; Piasecka-Kwiatkowska, D.; Springer, E. Allergenic Properties of Polish Nectar Honeys. Acta Sci. Pol. Technol. Aliment. 2020, 19. [CrossRef] [PubMed]

13. Cardona, V.; Ansotegui, I.J.; Ebisawa, M.; El-Gamal, Y.; Fernandez Rivas, M.; Fineman, S.; Geller, M.; Gonzalez-Estrada, A.; Greenberger, P.A.; Sanchez Borges, M.; et al. World Allergy Organization Anaphylaxis Guidance 2020. World Allergy Organ. J. 2020, 13, 100472. [CrossRef]

14. Jahnz-Rozyk, K.; Raciborski, F.; Śliwczyński, A.M.; Kłak, A.; Pinkas, J. Anaphylaxis in Poland: The Epidemiology and Direct Costs. Adv. Dermatol. Allergol. 2017, 34, 573-579. [CrossRef] [PubMed]

15. Schäfer, T. Epidemiologie der Insektengiftallergie. Allergo J. 2009, 18, 353-358. [CrossRef]

16. Bilò, B.M.; Bonifazi, F. Epidemiology of Insect-Venom Anaphylaxis. Curr. Opin. Allergy Clin. Immunol. 2008, 8, 330-337. [CrossRef]

17. Bonifazi, F.; Jutel, M.; Bilo, B.M.; Birnbaum, J.; Muller, U. The EAACI Interest Group on Insect Venom Hypersensitivity* Prevention and Treatment of Hymenoptera Venom Allergy: Guidelines for Clinical Practice. Allergy 2005, 60, 1459-1470. [CrossRef]

18. Dowbór-Dzwonka, A.; Cegła, B.; Filanowicz, M.; Szynkiewicz, E.; Bartuzi, Z. Hipersensytyzacja na Jady Błonkówek Hypersensitivity to Hymenoptera Venom. Hygeia 2012, 47, 157-163.

19. Cichocka-Jarosz, E. Hymenoptera Venom Allergy in Humans. Folia Med. Crac. 2012, 52, 43-60.

20. Nittner-Marszalska, M.; Liebhart, J.; Liebhart, E.; Dor, A.; Dobek, R.; Obojski, A.; Medrala, W. Prevalence of Hymenoptera Venom Allergy and Its Immunological Markers Current in Adults in Poland. Med. Sci. Monit. Int. Med. J. Exp. Clin. Res. 2004, 10, CR324-CR329.

21. Rajan, T.V. The Gell-Coombs Classification of Hypersensitivity Reactions: A Re-Interpretation. TRENDS Immunol. 2003, 24, 376-379. [CrossRef] 
22. Fehr, D.; Micaletto, S.; Moehr, T.; Schmid-Grendelmeier, P. Risk Factors for Severe Systemic Sting Reactions in Wasp (Vespula Spp.) and Honeybee (Apis Mellifera) Venom Allergic Patients. Clin. Transl. Allergy 2019, 9, 54. [CrossRef]

23. Simons, F.E.R. Anaphylaxis. J. Allergy Clin. Immunol. 2010, 125, S161-S181. [CrossRef]

24. Törő, K.; Borka, K.; Kardos, M.; Kristóf, I.; Sótonyi, P. Expression and Function of C5a Receptor in a Fatal Anaphylaxis After Honey Bee Sting. J. Forensic Sci. 2011, 56, 526-528. [CrossRef] [PubMed]

25. Nittner-Marszalska, M.; Kopeć, A.; Biegus, M.; Kosińska, M.; Obojski, A.; Pawłowicz, R.; Gillert-Smutnicka, M.; Panaszek, B. Non-ST Segment Elevation Myocardial Infarction after Multiple Bee Stings. A Case of "Delayed" Kounis II Syndrome? Int. J. Cardiol. 2013, 166, e62-e65. [CrossRef]

26. Cichocka-Jarosz, E.; Stobiecki, M.; Nittner-Marszalska, M.; Jedynak-Wassowicz, U.; Brzyski, P.; Immunotherapy Section of the Polish Society of Allergology Working Group. Venom Allergy Treatment Practices in Poland in Comparison to Guidelines: Next Edition of the National Audit. Adv. Dermatol. Allergol. 2019, 36, 346-353. [CrossRef]

27. Mueller, H.L. Diagnosis and Treatment of Insect Sensitivity. J. Asthma Res. 1966, 3, 331-333. [CrossRef] [PubMed]

28. Golden, D.B.K.; Demain, J.; Freeman, T.; Graft, D.; Tankersley, M.; Tracy, J.; Blessing-Moore, J.; Bernstein, D.; Dinakar, C.; Greenhawt, M.; et al. Stinging Insect Hypersensitivity. Ann. Allergy Asthma Immunol. 2017, 118, 28-54. [CrossRef]

29. Sturm, G.J.; Varga, E.-M.; Roberts, G.; Mosbech, H.; Bilò, M.B.; Akdis, C.A.; Antolín-Amérigo, D.; Cichocka-Jarosz, E.; Gawlik, R.; Jakob, T.; et al. EAACI Guidelines on Allergen Immunotherapy: Hymenoptera Venom Allergy. Allergy 2018, 73, 744-764. [CrossRef] [PubMed]

30. Roumana, A.; Pitsios, C.; Vartholomaios, S.; Kompoti, E.; Kontou-Fili, K. The Safety of Initiating Hymenoptera Immunotherapy at 1 $\mathrm{Mg}$ of Venom Extract. J. Allergy Clin. Immunol. 2009, 124, 379-381. [CrossRef] [PubMed]

31. Nittner-Marszalska, M. Venom Immunotherapy. Alergol. Pol. Pol. J. Allergol. 2018, 5, 85-93. [CrossRef]

32. Incorvaia, C.; Frati, F.; Dell'Albani, I.; Robino, A.; Cattaneo, E.; Mauro, M.; David, M.; Qualizza, R.; Pastorello, E. Safety of Hymenoptera Venom Immunotherapy: A Systematic Review. Expert Opin. Pharmacother. 2011, 12, 2527-2532. [CrossRef]

33. Kołaczek, A.; Skorupa, D.; Antczak-Marczak, M.; Kuna, P.; Kupczyk, M. Safety and Efficacy of Venom Immunotherapy: A Real Life Study. Adv. Dermatol. Allergol. 2017, 2, 159-167. [CrossRef] [PubMed]

34. Matysiak, J.; Matysiak, J.; Kokot, Z.J.; Bręborowicz, A. Hymenoptera Venom Allergy with Special Emphasis on Honeybee (Apis Mellifera)—Current Knowledge. Alerg. Astma Immunol. 2011, 16, 163-171. (In Polish)

35. Boyce, J.A.; Assa'ad, A.; Burks, A.W.; Jones, S.M.; Sampson, H.A.; Wood, R.A.; Plaut, M.; Cooper, S.F.; Fenton, M.J.; Arshad, S.H.; et al. Guidelines for the Diagnosis and Management of Food Allergy in the United States: Summary of the NIAID-Sponsored Expert Panel Report. J. Allergy Clin. Immunol. 2010, 126, 1105-1118. [CrossRef] [PubMed]

36. Sahiner, U.M.; Durham, S.R. Hymenoptera Venom Allergy: How Does Venom Immunotherapy Prevent Anaphylaxis From Bee and Wasp Stings? Front. Immunol. 2019, 10, 1959. [CrossRef]

37. Incorvaia, C.; Mauro, M.; Pravettoni, V.; Pucci, S. Hypersensitivity to Hymenoptera Venom: Advances in Diagnosis and Implications for Treatment. Recent Pat. Inflamm. Allergy Drug Discov. 2011, 5, 128-135. [CrossRef]

38. Incorvaia, C.; Mauro, M.; Pastorello, E.A. Hymenoptera Stings in Conscripts. Allergy 1997, 52, 680-681. [CrossRef]

39. van de Veen, W.; Stanic, B.; Yaman, G.; Wawrzyniak, M.; Söllner, S.; Akdis, D.G.; Rückert, B.; Akdis, C.A.; Akdis, M. IgG4 Production Is Confined to Human IL-10-Producing Regulatory B Cells That Suppress Antigen-Specific Immune Responses. J. Allergy Clin. Immunol. 2013, 131, 1204-1212. [CrossRef]

40. Mikulski, D.; Smorawska-Sabanty, E.; Kowalski, M.L. Quality of Life in Patients Allergic to Hymenoptera Venom Who Refuse Specific Immunotherapy. Alerg. Astma Immunol. 2016, 21, 133-137. (In Polish)

41. Boyle, R.J.; Elremeli, M.; Hockenhull, J.; Cherry, M.G.; Bulsara, M.K.; Daniels, M.; Oude Elberink, J.N.G. Venom Immunotherapy for Preventing Allergic Reactions to Insect Stings. Cochrane Database Syst. Rev. 2012, 10. [CrossRef] [PubMed]

42. Dhami, S.; Zaman, H.; Varga, E.-M.; Sturm, G.J.; Muraro, A.; Akdis, C.A.; Antolín-Amérigo, D.; Bilò, M.B.; Bokanovic, D.; Calderon, M.A.; et al. Allergen Immunotherapy for Insect Venom Allergy: A Systematic Review and Meta-Analysis. Allergy 2017, 72, 342-365. [CrossRef]

43. Ludman, S.W.; Boyle, R.J. Stinging Insect Allergy: Current Perspectives on Venom Immunotherapy. J. Asthma Allergy 2015, 8, 75-86. [CrossRef] [PubMed]

44. Chapman, M.D.; Pomés, A.; Breiteneder, H.; Ferreira, F. Nomenclature and Structural Biology of Allergens. J. Allergy Clin. Immunol. 2007, 119, 414-420. [CrossRef]

45. WHO/IUIS Allergen Nomenclature Home Page. Available online: http:/ /www.allergen.org/index.php (accessed on 14 April 2021).

46. Abd El-Wahed, A.A.; Khalifa, S.A.M.; Sheikh, B.Y.; Farag, M.A.; Saeed, A.; Larik, F.A.; Koca-Caliskan, U.; AlAjmi, M.F.; Hassan, M.; Wahabi, H.A.; et al. Bee Venom Composition: From Chemistry to Biological Activity. In Studies in Natural Products Chemistry; Elsevier: Amsterdam, The Netherlands, 2019; Volume 60, pp. 459-484. ISBN 978-0-444-64181-6.

47. Szókán, G.Y.; Horváth, J.; Almás, M.; Saftics, G.Y.; Palócz, A. Liquid Chromatographic Analysis and Separation of Polypeptide Components from Honey Bee Venoms. J. Liq. Chromatogr. 1994, 17, 3333-3349. [CrossRef]

48. Hossen, M.S.; Shapla, U.M.; Gan, S.H.; Khalil, M.I. Impact of Bee Venom Enzymes on Diseases and Immune Responses. Molecules 2016, 22, 25. [CrossRef]

49. Van Vaerenbergh, M.; Debyser, G.; Devreese, B.; de Graaf, D.C. Exploring the Hidden Honeybee (Apis Mellifera) Venom Proteome by Integrating a Combinatorial Peptide Ligand Library Approach with FTMS. J. Proteom. 2014, 99, 169-178. [CrossRef] 
50. Peiren, N.; Vanrobaeys, F.; de Graaf, D.C.; Devreese, B.; Van Beeumen, J.; Jacobs, F.J. The Protein Composition of Honeybee Venom Reconsidered by a Proteomic Approach. Biochim. Biophys. Acta BBA Proteins Proteom. 2005, 1752, 1-5. [CrossRef]

51. Blank, S.; Michel, Y.; Seismann, H.; Plum, M.; Greunke, K.; Grunwald, T.; Bredehorst, R.; Ollert, M.; Braren, I.; Spillner, E. Evaluation of Different Glycoforms of Honeybee Venom Major Allergen Phospholipase A2 (Api m 1) Produced in Insect Cells. Protein Pept. Lett. 2011, 18, 415-422. [CrossRef]

52. Peiren, N.; de Graaf, D.C.; Brunain, M.; Bridts, C.H.; Ebo, D.G.; Stevens, W.J.; Jacobs, F.J. Molecular Cloning and Expression of Icarapin, a Novel IgE-Binding Bee Venom Protein. FEBS Lett. 2006, 580, 4895-4899. [CrossRef] [PubMed]

53. Kettner, A.; Hughes, G.J.; Frutiger, S.; Astori, M.; Roggero, M.; Spertini, F.; Corradin, G. Api m 6: A New Bee Venom Allergen. J. Allergy Clin. Immunol. 2001, 107, 914-920. [CrossRef] [PubMed]

54. Alvarez-Cuesta, E.; Bousquet, J.; Canonica, G.W.; Durham, S.R.; Malling, H.-J.; Valovirta, E. Standards for Practical AllergenSpecific Immunotherapy. Allergy 2006, 61, 1-3. [CrossRef]

55. Bilo, B.M.; Rueff, F.; Mosbech, H.; Bonifazi, F.; Oude-Elberink, J.N.G. The EAACI Interest Group on Insect Venom Hypersensitivity* Diagnosis of Hymenoptera Venom Allergy. Allergy 2005, 60, 1339-1349. [CrossRef] [PubMed]

56. Matysiak, J.; Schmelzer, C.E.H.; Neubert, R.H.H.; Kokot, Z.J. Characterization of Honeybee Venom by MALDI-TOF and NanoESIQqTOF Mass Spectrometry. J. Pharm. Biomed. Anal. 2011, 54, 273-278. [CrossRef]

57. Hoffman, D.R.; Weimer, E.T.; Sakell, R.H.; Schmidt, M. Sequence and Characterization of Honeybee Venom Acid Phosphatase. J. Allergy Clin. Immunol. 2005, 115, S107. [CrossRef]

58. Zhou, J.; Zhao, J.; Zhang, S.; Shen, J.; Qi, Y.; Xue, X.; Li, Y.; Wu, L.; Zhang, J.; Chen, F.; et al. Quantification of Melittin and Apamin in Bee Venom Lyophilized Powder from Apis Mellifera by Liquid Chromatography-Diode Array Detector-Tandem Mass Spectrometry. Anal. Biochem. 2010, 404, 171-178. [CrossRef] [PubMed]

59. Ionete, R.E.; Dinca, O.R.; Tamaian, R.; Geana, E.I. Exploring Apis Mellifera Venom Compounds Using Highly Efficient Methods. Smart Energy Sustain. Environ. 2013, 16, 89-100.

60. Kelley, L.A.; Mezulis, S.; Yates, C.M.; Wass, M.N.; Sternberg, M.J.E. The Phyre2 Web Portal for Protein Modeling, Prediction and Analysis. Nat. Protoc. 2015, 10, 845-858. [CrossRef]

61. Kelley, L.A.; Sternberg, M.J.E. Protein Structure Prediction on the Web: A Case Study Using the Phyre Server. Nat. Protoc. 2009, 4, 363-371. [CrossRef]

62. PHYRE Protein Fold Recognition Server. Available online: http://www.sbg.bio.ic.ac.uk/phyre2/html/help.cgi?id=help/ interpret_normal (accessed on 28 July 2021).

63. UniProt. Available online: https:/ /www.uniprot.org/ (accessed on 18 April 2021).

64. Hofmann, S.C.; Pfender, N.; Weckesser, S.; Huss-Marp, J.; Jakob, T. Added Value of IgE Detection to rApi m 1 and rVes v 5 in Patients with Hymenoptera Venom Allergy. J. Allergy Clin. Immunol. 2011, 127, 265-267. [CrossRef]

65. Korošec, P.; Valenta, R.; Mittermann, I.; Celesnik, N.; Eržen, R.; Zidarn, M.; Košnik, M. Low Sensitivity of Commercially Available rApi $\mathrm{m} 1$ for Diagnosis of Honeybee Venom Allergy. J. Allergy Clin. Immunol. 2011, 128, 671-673. [CrossRef]

66. Sturm, G.J.; Hemmer, W.; Hawranek, T.; Lang, R.; Ollert, M.; Spillner, E.; Blank, S.; Bokanovic, D.; Aberer, W. Detection of IgE to Recombinant Api $\mathrm{m} 1$ and RVes v 5 Is Valuable but Not Sufficient to Distinguish Bee from Wasp Venom Allergy. J. Allergy Clin. Immunol. 2011, 128, 247-248. [CrossRef]

67. Köhler, J.; Blank, S.; Müller, S.; Bantleon, F.; Frick, M.; Huss-Marp, J.; Lidholm, J.; Spillner, E.; Jakob, T. Component Resolution Reveals Additional Major Allergens in Patients with Honeybee Venom Allergy. J. Allergy Clin. Immunol. 2014, 133, 1383-1389. [CrossRef]

68. Müller, U.R.; Johansen, N.; Petersen, A.B.; Fromberg-Nielsen, J.; Haeberli, G. Hymenoptera Venom Allergy: Analysis of Double Positivity to Honey Bee and Vespula Venom by Estimation of IgE Antibodies to Species-Specific Major Allergens Api m 1 and Ves v 5. Allergy 2009, 64, 543-548. [CrossRef] [PubMed]

69. Stoevesandt, J.; Hosp, C.; Kerstan, A.; Trautmann, A. Sensitization to Hymenoptera Venom Marker Allergens: Prevalence, Predisposing Factors, and Clinical Implications. Clin. Exp. Allergy 2018, 48, 1735-1743. [CrossRef] [PubMed]

70. Frick, M.; Müller, S.; Bantleon, F.; Huss-Marp, J.; Lidholm, J.; Spillner, E.; Jakob, T. rApi m 3 and rApi m 10 Improve Detection of Honey Bee Sensitization in Hymenoptera Venom-Allergic Patients with Double Sensitization to Honey Bee and Yellow Jacket Venom. Allergy 2015, 70, 1665-1668. [CrossRef] [PubMed]

71. Grunwald, T.; Bockisch, B.; Spillner, E.; Ring, J.; Bredehorst, R.; Ollert, M.W. Molecular Cloning and Expression in Insect Cells of Honeybee Venom Allergen Acid Phosphatase (Api m 3). J. Allergy Clin. Immunol. 2006, 117, 848-854. [CrossRef] [PubMed]

72. Blank, S.; Seismann, H.; Bockisch, B.; Braren, I.; Cifuentes, L.; McIntyre, M.; Rühl, D.; Ring, J.; Bredehorst, R.; Ollert, M.W.; et al. Identification, Recombinant Expression, and Characterization of the 100 KDa High Molecular Weight Hymenoptera Venom Allergens Api m 5 and Ves v 3. J. Immunol. 2010, 184, 5403-5413. [CrossRef]

73. Michel, Y.; McIntyre, M.; Ginglinger, H.; Ollert, M.; Cifuentes, L.; Blank, S.; Spillner, E. The Putative Serine Protease Inhibitor Api m 6 from Apis Mellifera Venom: Recombinant and Structural Evaluation. J. Investig. Allergol. Clin. Immunol. 2012, 22, 476-484. [PubMed]

74. Api m 8 Allergen Details. Available online: http:/ / www.allergen.org/viewallergen.php?aid=73 (accessed on 23 April 2021 ).

75. Blank, S.; Seismann, H.; Michel, Y.; McIntyre, M.; Cifuentes, L.; Braren, I.; Grunwald, T.; Darsow, U.; Ring, J.; Bredehorst, R.; et al. Api m 10, a Genuine A. Mellifera Venom Allergen, Is Clinically Relevant but Underrepresented in Therapeutic Extracts: Api m 10 Is Underrepresented in Therapeutic Extracts. Allergy 2011, 66, 1322-1329. [CrossRef] 
76. Blank, S.; Bantleon, F.I.; McIntyre, M.; Ollert, M.; Spillner, E. The Major Royal Jelly Proteins 8 and 9 (Api m 11) Are Glycosylated Components of Apis Mellifera Venom with Allergenic Potential beyond Carbohydrate-Based Reactivity. Clin. Exp. Allergy 2012, 42, 976-985. [CrossRef] [PubMed]

77. Blank, S.; Seismann, H.; McIntyre, M.; Ollert, M.; Wolf, S.; Bantleon, F.I.; Spillner, E. Vitellogenins Are New High Molecular Weight Components and Allergens (Api m 12 and Ves v 6) of Apis Mellifera and Vespula Vulgaris Venom. PLoS ONE 2013, 8, e62009. [CrossRef] [PubMed]

78. Francese, S.; Lambardi, D.; Mastrobuoni, G.; Marca, G.; Moneti, G.; Turillazzi, S. Detection of Honeybee Venom in Envenomed Tissues by Direct MALDI MSI. J. Am. Soc. Mass Spectrom. 2009, 20, 112-123. [CrossRef]

79. Ferreira, R.S., Jr.; Sciani, J.M.; Marques-Porto, R.; Lourenço, A., Jr.; de Orsi, R.; Barraviera, B.; Pimenta, D.C. Africanized Honey Bee (Apis Mellifera) Venom Profiling: Seasonal Variation of Melittin and Phospholipase A2 Levels. Toxicon 2010, 56, 355-362. [CrossRef] [PubMed]

80. Dennis, E.A.; Cao, J.; Hsu, Y.-H.; Magrioti, V.; Kokotos, G. Phospholipase A2 Enzymes: Physical Structure, Biological Function, Disease Implication, Chemical Inhibition, and Therapeutic Intervention. Chem. Rev. 2011, 111, 6130-6185. [CrossRef] [PubMed]

81. Cezmi, A.A.; Mubeccel, A. Mechanisms of Allergen-Specific Immunotherapy. J. Allergy Clin. Immunol. 2011, 127, 18-27. [CrossRef]

82. Król, A.; Ostrowski, M. Enzymatic and Non-Enzymatic Functions of Secreted Phospholipases A2. Postepy Biochem. 2017, 63, 198-204. (In Polish) [PubMed]

83. Matysiak, J.; Klupczynska, A.; Kokot, Z.J. Importance of Hyaluronidases in Contemporary Medicine. Now. Lek 2013, 82, 156-162. (In Polish)

84. Girish, K.S.; Kemparaju, K. The Magic Glue Hyaluronan and Its Eraser Hyaluronidase: A Biological Overview. Life Sci. 2007, 80, 1921-1943. [CrossRef]

85. Stern, R. Devising a Pathway for Hyaluronan Catabolism: Are We There Yet? Glycobiology 2003, 13, 105R-115R. [CrossRef]

86. Marković-Housley, Z.; Miglierini, G.; Soldatova, L.; Rizkallah, P.J.; Müller, U.; Schirmer, T. Crystal Structure of Hyaluronidase, a Major Allergen of Bee Venom. Structure 2000, 8, 1025-1035. [CrossRef]

87. Perez-Riverol, A.; Lasa, A.M.; dos Santos-Pinto, J.R.A.; Palma, M.S. Insect Venom Phospholipases A1 and A2: Roles in the Envenoming Process and Allergy. Insect Biochem. Mol. Biol. 2019, 105, 10-24. [CrossRef] [PubMed]

88. Antonicelli, L.; Bilò, M.B.; Bonifazi, F. Epidemiology of Hymenoptera Allergy. Curr. Opin. Allergy Clin. Immunol. 2002, 2, 341-346. [CrossRef] [PubMed]

89. De Lima, P.R.; Brochetto-Braga, M.R. Hymenoptera Venom Review Focusing on Apis Mellifera. J. Venom. Anim. Toxins Incl. Trop. Dis. 2003, 9, 149-162. [CrossRef]

90. Hoffman, D.R. Hymenoptera Venom Allergens. Clin. Rev. Allergy Immunol. 2006, 30, 109-128. [CrossRef]

91. Brown, L.R.; Lauterwein, J.; Wüthrich, K. High-Resolution 1H-NMR Studies of Self-Aggregation of Melittin in Aqueous Solution. Biochim. Biophys. Acta BBA Protein Struct. 1980, 622, 231-244. [CrossRef]

92. Park, D.; Jung, J.W.; Lee, M.O.; Lee, S.Y.; Kim, B.; Jin, H.J.; Kim, J.; Ahn, Y.-J.; Lee, K.W.; Song, Y.S.; et al. Functional Characterization of Naturally Occurring Melittin Peptide Isoforms in Two Honey Bee Species, Apis Mellifera and Apis Cerana. Peptides 2014, 53, 185-193. [CrossRef] [PubMed]

93. Pesek, R.D.; Lockey, R.F. Management of Insect Sting Hypersensitivity: An Update. Allergy Asthma Immunol. Res. 2013, 5, 129. [CrossRef]

94. Chen, J.; Guan, S.-M.; Sun, W.; Fu, H. Melittin, the Major Pain-Producing Substance of Bee Venom. Neurosci. Bull. 2016, 32, 265-272. [CrossRef] [PubMed]

95. Wachinger, M.; Saermark, T.; Erfle, V. Influence of Amphipathic Peptides on the HIV-1 Production in Persistently Infected T Lymphoma Cells. FEBS Lett. 1992, 309, 235-241. [CrossRef]

96. Okamoto, T.; Isoda, H.; Kubota, N.; Takahata, K.; Takahashi, T.; Kishi, T.; Nakamura, T.Y.; Muromachi, Y.; Matsui, Y.; Goshima, K. Melittin Cardiotoxicity in Cultured Mouse Cardiac Myocytes and Its Correlation with Calcium Overload. Toxicol. Appl. Pharmacol. 1995, 133, 150-163. [CrossRef]

97. Nabil, Z.I.; Hussein, A.A.; Zalat, S.M.; Kh Rakha, M. Mechanism of Action of Honey Bee (Apis Mellifera L.) Venom on Different Types of Muscles. Hum. Exp. Toxicol. 1998, 17, 185-190. [CrossRef]

98. Han, H.J.; Lee, J.H.; Park, S.H.; Choi, H.J.; Yang, I.S.; Mar, W.C.; Kang, S.K.; Lee, H.J. Effect of Bee Venom and Its Melittin on Apical Transporters of Renal Proximal Tubule Cells. Kidney Blood Press. Res. 2000, 23, 393-399. [CrossRef] [PubMed]

99. Sumikura, H.; Andersen, O.K.; Drewes, A.M.; Arendt-Nielsen, L. A Comparison of Hyperalgesia and Neurogenic Inflammation Induced by Melittin and Capsaicin in Humans. Neurosci. Lett. 2003, 337, 147-150. [CrossRef]

100. Hoffman, D.R.; Shipman, W.H.; Babin, D. Allergrns in Be Venom. II. Two New High Molecular Weight Allergenic Specificities. J. Allergy Clin. Immunol. 1977, 59, 147-153. [CrossRef]

101. Winningham, K.M.; Fitch, C.D.; Schmidt, M.; Hoffman, D.R. Hymenoptera Venom Protease Allergens. J. Allergy Clin. Immunol. 2004, 114, 928-933. [CrossRef]

102. Georgieva, D.; Greunke, K.; Betzel, C. Three-Dimensional Model of the Honeybee Venom Allergen Api m 7: Structural and Functional Insights. Mol. Biosyst. 2010, 6, 1056-1060. [CrossRef] [PubMed]

103. Venom Serine Carboxypeptidase Precursor-Apis Mellifera (Honeybee). Available online: https://www.uniprot.org/uniprot/ C9WMM5 (accessed on 17 April 2021). 
104. Jakob, T.; Rauber, M.M.; Perez-Riverol, A.; Spillner, E.; Blank, S. The Honeybee Venom Major Allergen Api m 10 (Icarapin) and Its Role in Diagnostics and Treatment of Hymenoptera Venom Allergy. Curr. Allergy Asthma Rep. 2020, 20, 48. [CrossRef]

105. Van Vaerenbergh, M.; De Smet, L.; Rafei-Shamsabadi, D.; Blank, S.; Spillner, E.; Ebo, D.G.; Devreese, B.; Jakob, T.; de Graaf, D.C. IgE Recognition of Chimeric Isoforms of the Honeybee (Apis Mellifera) Venom Allergen Api m 10 Evaluated by Protein Array Technology. Mol. Immunol. 2015, 63, 449-455. [CrossRef]

106. Frick, M.; Fischer, J.; Helbling, A.; Ruëff, F.; Wieczorek, D.; Ollert, M.; Pfützner, W.; Müller, S.; Huss-Marp, J.; Dorn, B.; et al. Predominant Api m 10 Sensitization as Risk Factor for Treatment Failure in Honey Bee Venom Immunotherapy. J. Allergy Clin. Immunol. 2016, 138, 1663-1671. [CrossRef]

107. Schmitzová, J.; Klaudiny, J.; Albert, Š.; Schröder, W.; Schreckengost, W.; Hanes, J.; Júdová, J.; Šimúth, J. A Family of Major Royal Jelly Proteins of the Honeybee Apis Mellifera L. Cell. Mol. Life Sci. 1998, 54, 1020-1030. [CrossRef]

108. Santos, K.; Delazaridossantos, L.; Anitamendes, M.; Monsondesouza, B.; Malaspina, O.; Palma, M. Profiling the Proteome Complement of the Secretion from Hypopharyngeal Gland of Africanized Nurse-Honeybees (Apis Mellifera L.). Insect Biochem. Mol. Biol. 2005, 35, 85-91. [CrossRef] [PubMed]

109. Thien, F.C.K.; Leung, R.; Baldo, B.A.; Weinbr, J.A.; Plomley, R.; Czarny, D. Asthma and Anaphylaxis Induced by Royal Jelly. Clin. Exp. Allergy 1996, 26, 216-222. [CrossRef]

110. Hanes, J.; Šimuth, J. Identification and Partial Characterization of the Major Royal Jelly Protein of the Honey Bee (Apis Mellifera L.). J. Apic. Res. 1992, 31, 22-26. [CrossRef]

111. Albert, S.; Klaudiny, J. MRJP9, an Ancient Protein of the Honeybee MRJP Family with Non-Nutritional Function. J. Apic. Res. 2007, 46, 99-104. [CrossRef]

112. Leung, R.; Ho, A.; Chan, J.; Choy, D.; Lai, C.K.W. Royal Jelly Consumption and Hypersensitivity in the Community. Clin. Exp. Allergy 1997, 27, 333-336. [CrossRef] [PubMed]

113. Hayward, A.; Takahashi, T.; Bendena, W.G.; Tobe, S.S.; Hui, J.H.L. Comparative Genomic and Phylogenetic Analysis of Vitellogenin and Other Large Lipid Transfer Proteins in Metazoans. FEBS Lett. 2010, 584, 1273-1278. [CrossRef] 